\title{
Dangerous Equations? How Female-headed Households Became the Poorest of the Poor: Causes, Consequences and Cautions
}

\section{Sylvia Chant"}

\section{Introduction}

The idea that women bear a disproportionate and growing burden of poverty at a global scale, often encapsulated in the concept of a "feminisation of poverty", has become a virtual orthodoxy in recent decades, despite the dearth of reliable data on poverty, let alone its gender dimensions (Moghadam 1997). Yet, this has not dissuaded a large segment of the development community, including international agencies, from asserting that 60-70 per cent of the world's poor are female, and that tendencies to greater poverty among women are deepening. In broader work on poverty, and especially in policy circles, the poverty of female-headed households has effectively become a proxy for women's poverty, if not poverty in general, a set of "dangerous equations" which have been increasingly challenged (Chant 1997, 2003; Jackson 1996; Kabeer 1996).

The fact that female-headed households are a "visible and readily identifiable group in income poverty statistics' (Kabeer 1996: 14) provides fuel for a range of political agendas. In one respect, it serves neo-liberal enthusiasm for efficiency-driven targeting of poverty reduction measures to "exceptionally" disaffected parties. In another vein, highlighting the disadvantage of female-headed households has also catered to Gender and Development (GAD) interests by providing an apparently robust tactical peg on which to hang justification for allocating resources to women (Chant 2003; Jackson 1996).

This article explores some of the tensions emanating from growing equivocation over the links between female household headship and poverty. Setting out the principal reasons why women-headed households have traditionally been regarded (and portrayed) as the "poorest of the poor", the article examines evidence that has been used to support or challenge this orthodoxy. It then proceeds to focus on social and policy implications, from the problems of targeting to the need to maintain high visibility of gender in the face of shrinking resources for development and/or social assistance. The article concludes with reflection on the potential outcomes of surrendering a conventional wisdom that has undoubtedly helped to harness resources for women.

\section{How women-headed households became the "poorest of the poor" 2.1 Key rationales}

In the last $10-15$ years, pronouncements about women-headed households being the "poorest of the poor" have proliferated in writings on gender (see Chant 2003 for examples). Often made without direct reference to empirical data, the assumption in such statements that women-headed households face an above-average risk of poverty is by no means groundless. Indeed, there are persuasive reasons why we might expect a group disadvantaged by their gender to be further disadvantaged by allegedly "incomplete" or "under-resourced" household arrangements. This is especially so, given the assumption that female household headship is prone to arise in situations of economic privation and insecurity. 
The factors responsible for the "feminisation of poverty" have been linked with gender disparities in rights, entitlements and capabilities, the genderdifferentiated impacts of neo-liberal restructuring, the informalisation and feminisation of labour, and the erosion of kin-based support networks through migration, conflict and so on. However, a primary tenet has been the mounting incidence of female household headship, and in some circles the "culture of single motherhood" has been designated the "New Poverty Paradigm" (Thomas 1994). The links so frequently drawn between the "feminisation of poverty" and household headship derive from the idea that women-headed households constitute a disproportionate number of the poor, and that they experience greater extremes of poverty than maleheaded units. An additional element, commonly referred to as an 'intergenerational transmission of disadvantage', is that the privation of female household heads is passed on to their children (Chant 1999), purportedly because female heads cannot 'properly support their families or ensure their wellbeing' (Mehra et al. 2000: 7).

Moghadam's (1997) extensive review of the "feminisation of poverty" identifies three main reasons which, prima facie, are likely to make women poorer than men. These are first, women's disadvantage in respect of poverty-inducing entitlements and capabilities; second, their heavier work burdens and lower earnings and third, constraints on socio-economic mobility due to cultural, legal and labour market barriers. Lone mother units are often assumed to be worse off than two-parent households because, in lacking a "breadwinning" partner they are not only deprived of an adult male's earnings, but have relatively more dependents to support. On the one hand, female heads are conjectured to have less time and energy to conserve resources, such as by shopping around for the cheapest foodstuffs. On the other, women's "reproduction tax" (Palmer 1992) cuts heavily into economic productivity, with lone mothers often confined to part-time, flexible, and/or home-based occupations. This is compounded by women's disadvantage in respect of education and training, their lower average earnings, gender discrimination in the workplace, and the fact that social and labour policies rarely provide more than minimal support for parenting.

In most parts of the South, there is little or no compensation for earnings shortfalls through "transfer payments" from external parties such as the State, or "absent fathers". As Bibars notes in relation to non-contributory poverty alleviation programmes in Egypt, 'The state has not provided women with an institutional alternative to the male provider' (Bibars 2001: 86). While in many places legislation governing maintenance payments has now extended to cover children born to couples in consensual unions, levels of "paternal responsibility" are notoriously low and men are seldom penalised for non-compliance (Budowski and Rosero-Bixby 2003; Chant 2003). Men may be unable, but also unwilling, to pay. In Costa Rica, for example, men tend to regard "family" as applying only to women and children with whom they are currently involved, and distance themselves from offspring of previous relationships (Chant 1997).

Another reason offered to account for their poverty is that female heads have smaller social networks, because they lack ties with ex-partners' relatives, or because they "keep themselves to themselves" in the face of hostility or mistrust on the part of their own family networks or others in their communities. Indeed, lone mothers may deliberately distance themselves from kin as a means of deflecting the "shame" or "dishonour" attached to out-of-wedlock birth and/or marriage failure, not to mention, in some instances, stigmatised types of employment such as sex work. Some female heads are unable to spare time to actively cultivate social links and/or may eschew seeking help from others because they cannot reciprocate (Chant 1997). Yet, as discussed in more detail later, we cannot necessarily assume that women heads lack transfers from external parties, that women's individual disadvantage maps directly onto the households they head, or that living with men automatically mitigates women's risks of poverty.

\section{Challenges to the construction of women-headed households as the "poorest of the poor"}

Challenges to "poorest of the poor" stereotyping have gathered increasing momentum on a number of grounds.

\subsection{Lack of "fit" with quantitative data}

There is actually very little "hard data" - even on the basis of aggregate household incomes - which reveal consistent links between female household headship and poverty. More critically, perhaps, there 
does not appear to be any notable relationship between trends in poverty and in the incidence of female headship over time. Although in some countries, such as Costa Rica, poverty among women heads is on the rise, Arriagada asserts for Latin America as a whole that: '... the majority of households with a female head are not poor and are those which have increased most in recent decades' (Arriagada 1998: 91). Research in this and other regions also indicates that children in femaleheaded households can actually be better off than their counterparts in male-headed units (see Chant 2003 for discussion and references).

Such findings clearly need to be balanced against research, which indicates that women-headed households are likely to be poorer than male-headed units. One of the most ambitious comparative reviews to date, based on over 60 studies from Latin America, Africa and Asia, concluded that in twothirds of cases, households headed by women were poorer than those headed by men (Buvinic and Gupta 1997). Nonetheless, given conflicting and often tenuous evidence for any systematic relationship between female household headship and poverty, blanket generalisations are unhelpful. In fact, given widespread economic inequalities between women and men, it is perhaps more important to ask how substantial numbers of female heads succeed in evading the status of "poorest of the poor".

\subsection{Heterogeneity of female-headed households}

That links between female household headship and poverty may not be as definitive as suggested by "feminisation of poverty" orthodoxy owes in part to the heterogeneity of women-headed units. This heterogeneity, which can have important mediating effects on poverty, hinges on variations in women's routes into headship - for example, by "choice" or involuntarily, and/or through marriage, separation, widowhood and so on. Other axes of diversity include rural versus urban residence, household composition, stage in the life course (including age and relative dependency of offspring) and access to resources from beyond the household. While female heads as individuals may have to contend with discrimination, above-average work burdens and time constraints, their personal disadvantage as women may be compensated by contributions from other co-resident individuals as well as migrant family members. One strategy is to invite coresidence by extended kin, which can increase productive and reproductive labour supply, bolster earning capacity and reduce vulnerability (Chant 2003). As Wartenburg (1999) notes for Colombia, the manner in which female-headed households organise themselves can help to neutralise the negative effects of gender bias.

\subsection{Intra-household resource distribution}

Feminist research has revealed that households are sites of competing claims, rights, power, interests and resources, with negotiations frequently shaped by differences according to age, gender, position in the family hierarchy and so on. Popularised most widely in the shape of Amartya Sen's 'cooperative conflict' model, this perspective requires abandoning the notion that households are intrinsically cohesive, internally undifferentiated entities governed by "natural" proclivities to benevolence, consensus and joint welfare maximisation.

Acknowledging the need to avoid essentialising constructions of "female altruism" and "male egoism", a remarkable number of studies have found that women devote the bulk (if not all) of their earnings to household expenditure, often with positive effects on other members' nutritional intake, health care and education. Men, on the other hand, are prone to retain more of their earnings for discretionary personal expenditure. In some instances men's privileged bargaining position allows them to command an even larger share of resources than they actually bring to the household (Folbre 1991). Along with reducing the resources available to other household members, irregularity in financial contributions can lead to serious vulnerability and "secondary poverty" among women and children.

Even if female heads have lower incomes than their male counterparts, relative disadvantage may be mediated by the extent and manner in which income and assets are converted (or not) into consumption (and investments) which benefit the household as a whole. In this light, the absence or loss of a male head may not precipitate destitution so much as enhance the economic security and well-being of other household members. Many women in Mexico, Costa Rica and the Philippines, for example, stress that they feel more secure financially without men, even when their own 
earnings are low and/or prone to fluctuation. They also claim to be better able to cope with hardship when they are not at the mercy of male dictat and are freer to make their own decisions (Chant 1997). Critically, therefore, even if women are poorer in income terms as heads of their own household, they may feel they are better off and, importantly, less vulnerable. As Davids and van Driel put it, 'a lower income may even be preferred over a position of dependence and domination' (Davids and van Driel 2001: 164).

\subsection{Poverty as a multidimensional and subjective concept}

That command over resources may be deemed more important than level of resources in determining gendered experiences of poverty is further highlighted by "social deprivation" thinking about poverty which calls for holistic, multidimensional conceptualisations which incorporate people's subjectivities (Razavi 1999). Taking on board the multidimensionality of poverty provides important inroads into explaining why some low-income women make "trade-offs" between different forms of privation which, at face value, may seem prejudicial to their well-being. One such case is where female heads refuse offers of financial support from absent fathers in order to evade ongoing contact and/or sexual relations. Another instance is where women forfeit assets such as their homes or neighbourhood networks in order to exit abusive relationships.

It is also significant that while financial pressures may force some women to search for new partners following conjugal breakdown, others choose to remain alone rather than return to ex-partners or to form new relationships. As noted by Fonseca (1991) for Brazil, women who live without partners often do so not through lack of opportunity, but by choice. In many cases these are older (postmenopausal) women, who, 'having gained a moment of respite in the battlefield of the sexes' (Fonseca 1991: 157), prefer to rely upon sons than spouses. Recognising that not all female heads have access to financial help from sons or other male kin, and that a "high price" may have to be paid for independence (Jackson 1996), benefits in other dimensions of their lives may be adjudged to outweigh the costs.

Female headship is far from being a 'panacea for poverty' (Feijoó 1999: 162). It is clear that some women's individual endowments and household characteristics make them more vulnerable than others. Recognising that poverty is multi-causal and multi-facetted, and that, in some ways and in some cases, female household headship can be positive and empowering, is no justification for lack of assistance from state agencies and other institutional providers. How female heads might be best aided, however, needs serious consideration.

\section{Implications of competing constructions of female household headship and the links with poverty}

There is little doubt that the "feminisation of poverty" thesis has been powerful in pushing gender to the centre stage of international fora on poverty and social development, with women's economic empowerment now widely seen as crucial not only in achieving gender equality but eliminating poverty. Indeed, seeking to alleviate poverty through women seems to have become one of the most favoured routes to ensuring all-round developmental benefits:

Economic progression and improvements in the quality of life for all people is more rapidly achieved where women's status is higher. This is not simply a focus on a single individual, but because of women's communal role positive effects will be seen in the family, home, environment, children, elderly and whole communities and nations. (Finne 2001: 9)

While notions of "returns" or "pay-offs" from investing in women can clearly serve to secure resources for women, such naked instrumentalism leaves much to be desired. Moreover, whether linking poverty and female household headship is an appropriate part of the equation is another question. As Moore argues:

The straightforward assumption that poverty is always associated with female-headed households is dangerous, because it leaves the causes and nature of poverty unexamined and because it rests on the prior implication that children will be consistently worse-off in such households because they represent incomplete families. (Moore 1994: 61) 


\section{Female-headed households as the "poorest of the poor"}

Over and above the little substantive evidence that exists to suggest that women-headed households are the "poorest of the poor", a number of undesirable (if unintended) consequences result from seeing them as such. One is the suggestion that poverty is confined to female heads alone, which thereby overlooks the situation of the bulk of women in general (Jackson 1996). Davids and van Driel note:

The question that is not asked ... is whether women are better-off in male-headed households. By making male-headed households the norm, important contradictions vanish within these households, and so too does the possibly unbalanced economical [sic] and social position of women compared to men. (Davids and van Driel 2001: 162)

Lack of attention to intra-household inequalities in resource allocation, as we have seen, can also draw a veil over the "secondary poverty" often experienced by women in male-headed units (Chant 1997; González de la Rocha and Grinspun 2001), as well as wider structures of gender and socioeconomic inequality.

Persistent portrayals of the economic disadvantage of female-headed units not only misrepresent and devalue the enormous efforts made by female heads to overcome the problems they face on account of their gender, but also obliterate the meanings of female headship for women. As Davids and van Driel assert:

Female-headed households appear as an objective category of households in which the subject position of the female head vanishes completely as does the socio-cultural and psychological meaning that their status has for them personally. (Davids and van Driel 2001: 166)

Last, but not least, the tendency for static and universalising assumptions of the "feminisation of poverty" thesis to produce policy interventions which either target women in isolation or focus mainly on those who head their own households can neglect vital relational aspects of gender which are likely to play a large part in accounting for gender bias within and beyond the home (Buvinic and Gupta 1997; Jackson 1996). Some of these issues are discussed below in relation to the pros and cons of targeted programmes for female-headed households.

\subsection{Consequences and cautions of de-linking female household headship from poverty}

While there are many persuasive reasons to de-link female household headship from poverty, this can undermine the case for policy attention. Denying that households headed by women are the "poorest of the poor" potentially deprives them of resources which could enable them to overcome some of the inequities faced by women in general, and lone mothers in particular. Is this wise in a situation of diminishing public funds for social expenditure and increasing market-driven economic pressure on households, especially given that many femaleheaded households have struggled under the auspices of a "survival model" requiring high degrees of self-exploitation, that now looks to be exhausting its possibilities (González de la Rocha 2001)?

The answer here is probably no, but how femaleheaded households should be assisted merits more dedicated attention. One response to date has been to target such households in poverty programmes, as has occurred in various forms in Singapore, Cambodia, Iran, Bangladesh, India, Honduras, Puerto Rico, Chile, Colombia and Costa Rica. Although targeted initiatives remain relatively rare, they have grown in number in the last two decades. This is not only because of the momentum built up by "poorest of the poor" stereotyping, but because neo-liberal 'efficiency' strategies have favoured streamlining as a means of reducing public expenditure on universal social programmes.

\subsection{Pros and cons of targeted programmes for female-headed households living in poverty}

Recognising the empirical limitations of few "test cases", Buvinic and Gupta's (1997) review of the potential benefits and drawbacks of dedicated initiatives for female heads of household identifies three major arguments in favour of targeting. The first is that in situations where data on poverty are unreliable, isolating households headed by women is likely to capture a significant share of the 
population "in need", especially where there are substantial gaps in male and female earnings and where subsidised childcare facilities are limited. Second, targeting assistance to lone mothers may be effective in improving child welfare given widespread evidence that children fare better where women have resources at their own disposal. A third potential benefit is greater equitability in development spending between men and women.

Arguments against targeting include the fact that female-headed households may become maleheaded over time through remarriage or cohabitation, thereby resulting in a leakage of benefits to male-headed households (Buvinic and Gupta 1997). Another potential slippage of benefits is to non-poor households given that not all femaleheaded households have low incomes, and some may receive support, albeit periodically, from men. Further problems arise from difficulties inherent in screening processes whereby some female-headed households may not be classified as such due to cultural norms of naming men as heads of household, even if they are largely or permanently absent, or make little contribution to family life and welfare. Tactics for determining which types of female heads are most in need may also be problematic.

On top of this, many women may not want to be identified as lone mothers given the stigma attached to the status. They may also feel that taking public money will increase antagonism against them. In Egypt, for example, Bibars (2001) notes that whereas the predominantly male beneficiaries of mainstream contributory aid and welfare schemes are perceived as having "rights", the recipients of non-contributory programmes (who are mainly female), are regarded in the disparaging light of "charity cases", especially given build-up of a 'distrustful, punitive and contemptuous attitude towards female-headed households and the poor in general' in recent years. Buvinic and Gupta (1997) further highlight how targeting can alienate male household heads, especially where female heads are beneficiaries of assistance not perceived as "female-specific" such as housing subsidies and food coupons.

Another argument against targeting, particularly common among government bodies, is that it may produce so-called "perverse incentives" and encourage more households to opt for female headship. Fear of this has been so pronounced in
Costa Rica that when the Social Welfare Ministry established its first programme for female household heads in 1997, specific declaration was made in the supporting documentation that there was no intention to promote increases in lone motherhood. Moreover, subsequent programmes of a related nature, such as Amor Jóven for adolescent mothers, have been oriented as much to preventing rises in lone parenthood as assisting the client group (Chant 2003). Bibars comments for Egypt that free and unconditional assistance is thought not only to increase the numbers of female-headed households, but to encourage them 'to relax and not work' (Bibars 2001: 67).

Finally, we have to acknowledge the limited impacts of targeted schemes for female household heads when resources allocated are small and/or where broader structures of gender inequality remain intact. It is instructive that in Cuba, where although Castro's government has resisted providing special welfare benefits to female heads, policies favouring greater gender equality in general, high levels of female labour force participation and the availability of support services such as day care, have all made it easier for women to raise children alone (Safa 1995).

\subsection{Alternative strategies to address the "feminisation of poverty"}

Targeted approaches recognise barriers to wellbeing in female-headed households and should not on this count be abandoned. Efforts to address the putative "feminisation of poverty" could, however, be more effective if they were to acknowledge that women in male-headed households also suffer poverty. As Bradshaw suggests, women's poverty is not only multidimensional, but is also "multisectoral", namely 'women's poverty is experienced in different ways, at different times and in different "spaces" "(Bradshaw 2002: 12). One of the main differences between women in female- and male-headed units is that the former tend to face problems of a limited asset base, while the latter's main challenge may be restricted access to and control over household assets (Bradshaw 2002). Accordingly, gender inequality needs to be addressed within as well as beyond the boundaries of household units.

Interventions to reduce women's poverty, whether as heads of household or otherwise, have taken a number of forms. These include investing 
in women's capabilities, through education, health, vocational training and so on, and/or enhancing their access to assets such as employment, credit and housing. While such interventions potentially go some way to narrowing gender gaps in wellbeing, and have arguably moved into a new gear given increasing experimentation with "gender budgets" at national and local levels, the "private" sphere of home and family are often left out of the frame. This relative neglect of "family matters" is surprising given the common argument that it is families who benefit from reductions in women's poverty.

\section{Conclusion}

It is paradoxical that despite three decades of rhetoric and intervention to reduce gender inequality, women's poverty is said to be rising. Yet, while to talk of the "feminisation of poverty" as an on-going and/or inevitable process, and as intrinsically linked with the feminisation of household headship, is arguably over-drawn, this should not detract from the fact that the 'social relations of gender predict greater vulnerability among women' (Moghadam 1997: 41). Williams and Lee-Smith argue:

\section{Note}

* This article draws from research conducted under the auspices of a Leverhulme Major Research Fellowship, 2003-6 (Award No. F07004R). Thanks also go to Sarah Bradshaw, Monica Budowksi, Andrea Cornwall, María del Carmen Feijoó, Brian Linneker, Cathy McIlwaine,

\section{References}

Arriagada, I., 1998, 'Latin American families: convergences and divergences in models and policies', CEPAL Review, Vol 65: 85-102

Bibars, I., 2001, Victims and Heroines: Women, Welfare and the Egyptian State, London: Zed Books

Bradshaw, S., 2002, Gendered Poverties and Power Relations: Looking Inside Communities and Households, Managua: ICD, Embajada de Holanda, Puntos de Encuentro

Budowski, M. and Rosero-Bixby, L., 2003, 'Fatherless Costa Rica? Child acknowledgement and support among lone mothers', Journal of Comparative Family Studies, Vol 34 No 2: 229-54

Buvinic, M. and Gupta, G., 1997, 'Female-headed households and female-maintained families: are
The "feminisation of poverty" is more than a slogan: it is a marching call that impels us to question our assumptions about poverty itself by examining how it is caused, manifested and reduced, and to do this from a gender perspective. (Williams and Lee-Smith 2000: 1)

While consensus on different tenets of the "feminisation of poverty" thesis remains elusive, debates have drawn attention to the problems of generalising about women's poverty, and of engaging in superficial dualistic comparisons between maleand female-headed households. Even if it continues to be impossible to pin down exactly how many women are poor, which women are poor, and how they become and/or remain poor, unpacking the "feminisation of poverty", and problematising some of its core assumptions, broadens prospects for change. This not only signifies interventions to redress gender inequalities in different spaces, such as the labour market, legal institutions and the home, but those which confront different dimensions of poverty and inequality in ways which are personally, as well as pragmatically, meaningful to women.

Maxine Molyneux, Silvia Posocco and Ramya Subrahmanian for their helpful advice and comments. A longer and fully referenced version of this article is published as an LSE Gender Institute Working Paper (Chant 2003).

they worth targeting to reduce poverty in developing countries?', Economic Development and Cultural Change, Vol 45 No 2: 259-80

Chant, S., 2003, 'Female household headship and the feminisation of poverty: facts, fictions and forward strategies', New Working Paper Series, Issue 9, London: LSE Gender Institute (www.lse.ac.uk/Depts/GENDER/publications.ht m\#chant/)

Chant, S., 1999, 'Women-headed Households: Global Orthodoxies and Grassroots Realities', in H. Afshar and S. Barrientos (eds), Women, Globalisation and Fragmentation in the Developing World, Basingstoke: Macmillan

Chant, S., 1997, 'Women-headed households: poorest of the poor? Perspectives from Mexico, 
Costa Rica and the Philippines', IDS Bulletin, Vol 28 No 3: 26-48

Davids, T. and van Driel, F., 2001, 'Globalisation and Gender: Beyond Dichotomies', in F.J. Schuurman (ed.), Globalisation and Development Studies Challenges for the 21st Century, London: Sage: 153-75

Feijoó, M. del C., 1999, 'De pobres mujeres a mujeres pobres', in M. González de la Rocha (ed.), Divergencias del Modelo Tradicional: Hogares de Jefatura Femenina en América Latina, México DF: Centro de Investigaciones y Estudios Superiores en Antropología Social: 155-62

Finne, G., 2001, Feminisation of Poverty, Geneva: World Alliance of YMCAs, Global Programmes and Issues (www.ywca.int/programs)

Folbre, N., 1991, 'Women on Their Own: Global Patterns of Female Headship', in R.S. Gallin and A. Ferguson (eds), The Women and International Development Annual Vol 2, Boulder, Colorado: Westview Press: 69-126

Fonseca, C., 1991, 'Spouses, Siblings and Sex-linked Bonding: A Look at Kinship Organisation in a Brazilian Slum', in E. Jelin (ed.), Family, Household and Gender Relations in Latin America, London: Kegan Paul International/Paris: UNESCO: 133-60

González de la Rocha, M., 2001, 'From the resources of poverty to the poverty of resources: the erosion of a survival model', Latin American Perspectives, Vol 28 No 4: 72-100

González de la Rocha, M. and Grinspun, A., 2001, 'Private Adjustments: Households, Crisis and Work', in A. Grinspun (ed.), Choices for the Poor: Lessons from National Poverty Strategies, New York: UNDP: 55-87

Jackson, C., 1996, 'Rescuing gender from the poverty trap', World Development, Vol 24 No 3: 489-504

Kabeer, N., 1996, 'Agency, well-being and inequality: reflections on the gender dimensions of poverty', IDS Bulletin, Vol 27 No 1: 11-21
Mehra, R., Esim, S. and Simms, M., 2000, Fulfilling the Beijing Commitment: Reducing Poverty, Enhancing Women's Economic Options, Washington, D.C.: International Center for Research on Women

Moghadam, V., 1997, 'The feminisation of poverty: notes on a concept and trend', Women's Studies Occasional Paper 2, Illinois State University

Moore, H., 1994, 'Is there a crisis in the family?', Occasional Paper 3, Geneva: World Summit for Social Development

Palmer, I., 1992, 'Gender, Equity and Economic Efficiency in Adjustment Programmes', in $\mathrm{H}$. Afshar and C. Dennis (eds), Women and Adjustment Policies in the Third World, Houndmills, Basingstoke: Macmillan: 69-83

Razavi, S., 1999, 'Gendered poverty and well-being: introduction', Development and Change, Vol 30 No 3: 409-33

Safa, H., 1995, The Myth of the Male Breadwinner: Women and Industrialisation in the Caribbean, Boulder, Colorado: Westview Press

Thomas, S., 1994, 'From the culture of poverty to the culture of single motherhood: the new poverty paradigm', Women and Politics, Vol 14 No 2: 65-97

Wartenburg, L., 1999, 'Vulnerabilidad y Jefatura en los Hogares Urbanos Colombianos', in M. González de la Rocha (ed.), Divergencias del Modelo Tradicional: Hogares de Jefatura Femenina en América Latina, México DF: Centro de Investigaciones y Estudios Superiores en Antropología Social/Plaza y Valdés Editores: 77-96

Williams, C. and Lee-Smith, D., 2000, 'Feminisation of poverty: re-thinking poverty reduction from a gender perspective', Habitat Debate, Vol 6 No 4: 1-5 (www.unhabitat.org/HD) 